\title{
APPLYING AHP IN EVALUATION OF VIETNAMESE COMMERCIAL BANKS
}

\section{THANH- TUYEN TRAN*}

\author{
Scientific Research Office, Lac Hong University, No. 10 Huynh Van Nghe, Bien Hoa \\ City, Dong Nai, Vietnam
}

*Corresponding author: copcoi2@gmail.com

\begin{abstract}
Bank rankings are one of the ways to rate the bank system and to create competitive advantages, which have emerged as the central issue and considered as one of the most important organizational innovation. This research is objective to explore and to demonstrate utility of Analytic Hierarchy Process (AHP) application in banking for the purpose of proposing suitable model for partners evaluation and selecting banking strategic alliances in Vietnam. The AHP is applied to examine what criteria should be encompassed in evaluating and examining the importance weightings of influential criteria when ranking the bank system. In this study, a short review of literature regarding application AHP in banking decision-making is presented, focusing on partner evaluation criteria and methods to propose model for partner evaluation and selecting strategic banking for the current study. After a long process of calculation based on AHP, I have come up with the final rankings according expert's interview: ACB's percentages have change widely from each subcriterion; finally it gets $12.98 \%$ at the top of the list. Coming very closely downwards are $\mathrm{DAB}$, SeAbank etc., at the bottom of the rankings is SGB at $7.41 \%$. By this paper, author would contribute to the ranking process of the banking system, in general, and the special case of Vietnamese banking a very modern model to apply, then to choose the right alliance for further cooperation, not only for banking system but it can be applied for a lot of industries.
\end{abstract}

Received 2018-09-17; accepted 2018-11-09; published 2019-01-04.

2010 Mathematics Subject Classification. 91B02.

Key words and phrases. AHP; banking system; evaluating, rankings; experts.

(C2019 Authors retain the copyrights of their papers, and all open access articles are distributed under the terms of the Creative Commons Attribution License. 


\section{INTRODUCTION}

\subsection{Research Background}

Bank rankings are one of the ways to rate the bank system and to create competitive advantages, which have emerged as the central issue and considered as one of the most important organizational innovation. The facts of successful bank rankings demonstrate that choosing a right cooperative partner possibly decides the fate of the majority of strategic alliances [1].

In the new era of banking, bank ranking formation has been growing among the financial industry during the last decades [2]. Bank rankings often include units like mutual fund managing companies, asset management companies, securities brokerages and corporate finance companies. Financial mergers and financial rankings can bring some advantages in terms of improving financial structures, and promoting the operating performance of financial organizations [3]. In the context of related studies focusing on Vietnamese industries are increasing; the author explores that studies that examine the bank rankings formation between banks are still rare although synergies between banking are so significant ([4],[5])

The growth of banking system increases in parallel with the monetization degree of markets; thus the development in the banking sector mutually and deeply affects the other sectors of the economy, particularly real economy [6]. Over the past two decades, the Vietnamese government has undertaken a series of reforms to strengthen and modernize this sector in order to adapt to the rising household incomes and an increasing demand for retail banking services, which resulted from rapid economic growth [7]. Soon after the Vietnamese government lifted its ban on the establishment of new banks in the years 2000s, numerous new banks began operations. In 2006, the government responded to the excessive number of banks and this leads to the competition for capital among banks. There are various forms of competitive pressure, such as retaining new customers, providing new financial services and holding available businesses [8].

Some methods like mergers and alliance formation have now become an emergent issue for Vietnamese banks and some banks' top managers are trying to adopt these philosophies to improve their competitive advantage ([9],[10]). 
Bank rankings of financial organizations are closely linked to organizational performance, government policy, shareholder rights and customer satisfaction. It is essential for financial organizations to select their strategies carefully. Factors requiring consideration include various internal, external, qualitative and quantitative attributes, indicating that the selected problem is an analytical hierarchy issue [11]. A well-known approach that can effectively deal with this problem is the analytic hierarchy process (AHP) [12]. The AHP methodology involves separating a complex decision issue into elemental problems to establish a hierarchical model. When the decision problem is divided into smaller constituent parts in a hierarchy, pair-wise comparisons of the relative importance of elements are conducted at each level to establish a set of priorities.

AHP is widely employed in diverse fields, especially growing its effectiveness among the financial industry ([13], [14], [15]). For example, Korhonen and Voutilainen (2006) [16] studied alternative alliances between banks and insurance companies. Six different possible structure models for such alliances and nine criteria are used to evaluate the models. The use of the AHP focused the discussions on pair-wise comparisons. Based on the evaluations of the panel, the alternatives financial conglomerate and cross-selling agreement, and no overlapping service channels are most preferred. Seçme et al. (2009) [17] proposed a fuzzy multi-criteria decision model to evaluate the performances of banks. The largest five commercial banks of Turkish banking sector are examined and these banks are evaluated in terms of several financial and non-financial indicators. Fuzzy Analytic Hierarchy Process (FAHP) and Technique for Order Performance by Similarity to Ideal Solution (TOPSIS) methods are integrated in the proposed model. After the weights for a number of criteria are determined based on the opinions of experts using the FAHP method, these weights is input to the TOPSIS method to rank the banks. The results show that not only financial performance but also non-financial performance should be taken into account in a competitive environment.

Financial organizations have been globally studied, but few of these studies have examined the strategies used by banks in Vietnam for making decisions regarding bank rankings. Basing on the successful experiences of rankings which raises some rules for choosing strategic alliance partners, and gives a description of how to choose the best partner with $\mathrm{AHP}$, in this paper we have studied the bank rankings between 10 top Vietnamese banks 
that are already on the financial industry for the purpose of proposinga suitable model for partner evaluation and selecting banking strategic alliance for any financial organizations. The main objective of this study is applying AHP to examine what criteria should be encompassed in evaluating and examining the importance weightings of influential criteria when ranking the bank system.

\subsection{Research Objectives and Implications}

Our research objectives are to explore and to demonstrate utility of AHP application in banking for the purpose of proposing suitable model for partners evaluation and selecting banking strategic alliances in Vietnam. We want to apply AHP to examine what criteria should be encompassed in evaluating and examining the importance weightings of influential criteria when ranking the bank system. In this study, a short review of literature regarding application AHP in banking decision-making is presented, focusing on partner evaluation criteria and methods to propose model for partner evaluation and selecting strategic banking for the current study. Analytic Hierarchy Process (AHP) application in banking sector is growing most recently and has been seen as a high potential decision support tool in banking sector in the days to come. The use of AHP as a decision support tool is appreciated and interested by the author. This study reviews application of AHP in the finance sector with specific reference to banking.

Bank ranking is one of the most complex and ill-structured tasks faced by banks. In deriving these strategies bankers usually try to achieve multiple, and sometimes conflicting objectives such as profitability, growth, liquidity, and market share subject to constraints on credit and exchange risks and regulatory requirements [18]. However, it is safe to assume that the AHP methodology can be applied to other complex and ill-defined strategic issues faced by other banking institutions because when compared with existing techniques on the one hand, and with qualitative managerial judgment on the other hand, the AHP provides a useful, simple and powerful tool for dealing with strategic planning in banking [19].

As mentioned above, the alliance with a highly regarded financial services institution may give financial organizations and cooperative industries an opportunity to build a suitable strategic relationship. The proposed strategy may also attract the concerns and preferences 
of bank stakeholders. The results of this study provide a valuable reference for bank administrators.

This current study contributes to the two elements of practical application of AHP method and academic application of the field evaluating and then to form suitable business strategy for a financial institution in a developing country. By presenting and applying AHP to researches and analyzing the advantages and disadvantages of this method, it provides top managers in related areas with the ability to integrate the multi-attribute preferences of consumers using a hierarchical model to determine the bank's relative position in the marketplace. The suitability of AHP in examining bank selection by consumers for managerial decision making is demonstrated using an empirical analysis in a major metroPolitian area. Implications of the findings of this analysis for strategic planning in the areas of marketing mix and organizational characteristics of a bank are explored. Suggestions for application of AHP to other areas of financial services management are included.

The research method wasapplied in this research includes:

(1) Research discovery: to explore preliminary research issues that need as well as claims the research problem.

(2) Method of describing and comparing or the method of decision-making.

(3) Method of intergrated analysis towards the problem of assessing the quality and selecting suitable model for partner evaluation and bank rankings in Vietnam.

(4) Qualitative amd expert methods: to review evaluation criteria for selecting suitable model for partner evaluation and bank rankings in Vietnam.

(5) Quantitative research method: Collecting information and data in quantitative form. This method is used in the process of applying AHP to evaluate and bank rankings in Vietnam.

(6) Data are collected through the process of surveying and interviewing representatives of banks chief executives, managers and staff; practicing outdoor activities; company file documents; journal and newspapers. 


\section{LITERATURE REVIEW}

\subsection{Basic Concepts}

The application of AHP in banking sector is growing most recently, and it is being combined with conventional bank evaluation parameters in this study. First, the main and sub criteria for the evaluation of banks performance are discussed along with the alternative Banks. Then the literature for the selection of banks through its performance is given.

\section{Decision-Making Problem}

The availability of more choices makes the process of decision making complicated. Thus it becomes very arduous task to select from the array of choices. The problem becomes even more gigantic in case of emerging a fierce competition among banks. Decision making process thus becomes a complicated phenomenon when the best alliance can help bank increase competitive advantage and survive through competition. Many factors are involved in choosing a partner thus selection of best banks to form alliances will fall into the category of multi-criteria analysis problem.

\subsection{Decision-Making Using the Analytic Hierarchy Process}

In this section, we will describe problem with the Analytic Hierarchy Process which include its concept, functions, basic scales, practical applications, and illustrative examples. Finally, we analyze the advantages and limitations of AHP method.

\subsubsection{Concepts}

In previous studies, AHP was implemented to help decision maker to choose the best solution among several alternatives across multiple criteria. Decision-making is related to the level of intelligence, wisdom and creativity to satisfy basic needs, to have better selective choices and to increase productivity for the enterprises. Evaluating a decision requires several considerations such as the benefits derived from making the right decision, the costs, the risks, and losses resulting from the actions taken if the wrong decision is made. Decision-making methods range from variety of choices in order to use more suitable decision-making tools. In the 1970s, Thomas Saaty developed AHP as a way of making decision dealing with weapons tradeoffs, resource and asset allocation when he was a 
professor at the Wharton School of Business and a consultant with the Arms Control Disarmament Agency.

\subsubsection{Function of AHP}

AHP is a time-tested method that has been used to decide for many successful businesses worldwide. It uses the judgments of decision makers to form a decomposition of problems into hierarchies. Problem complexity is represented by the number of levels in the hierarchy which combine with the decision-makers model of the problem to be solved [12]. The hierarchy, as shown in figure 1, is used to derive ratio-scaled measures for decision alternatives and the relative value that alternatives have against organizational goals (customer satisfaction, product/service, financial, human resource, and organizational effectiveness) and project risks.

AHP uses matrix algebra to sort out factors to arrive at a mathematically optimal solution and derives ratio scales from paired comparisons of factors and choice options. AHP consists of four steps [20]. In the first step, the author defines the problem and state the goal or objective. In part two, the criteria or factors that influence the goal are made clear. In this step, the structure of these factors into levels and sublevels are also formed. In part three, the author uses paired comparisons of each factor with respect to each other that forms a comparison matrix with calculated weights, ranked eigen values, and consistency measures. In the final step, synthesize the ranks of alternatives until the final choice is made.

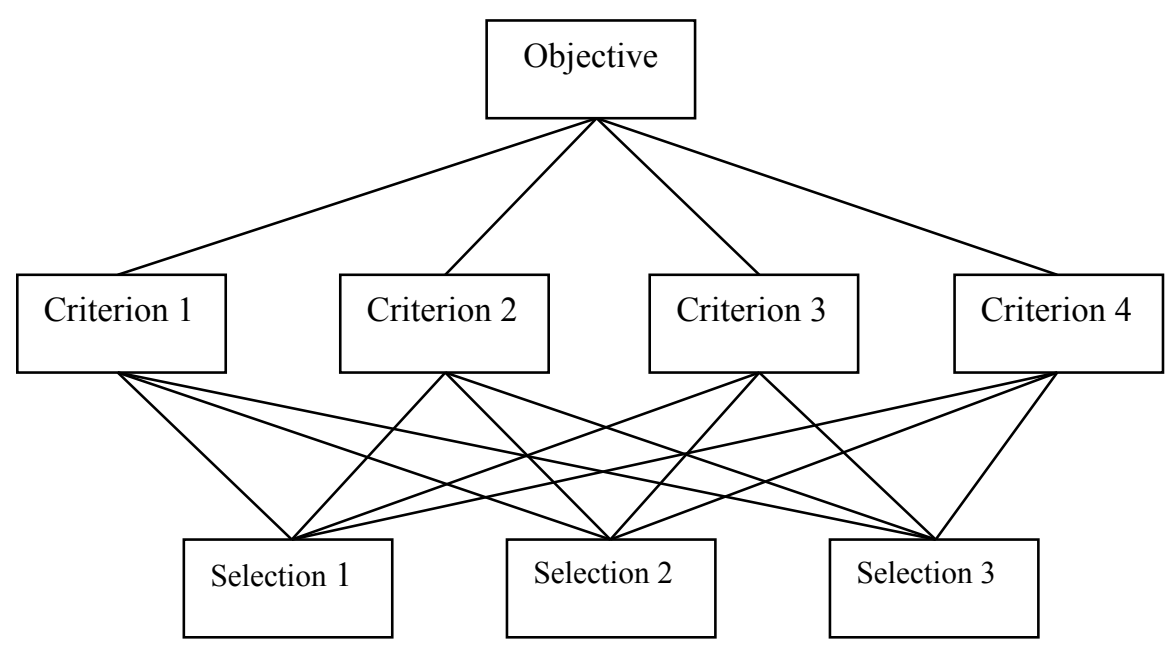

Figure 2.1: AHP hierarchy 


\subsubsection{AHP basic scales}

The paired comparison scales between the comparison pair (aij) of two items (item $\mathrm{i}$ and item $\mathrm{j}$ ) is as follows:

(itemi) 9-8-7-6-5-4-3-2-1-2-3-4-5-6-7-8-9 (item j)

The preference scale for pair-wise comparisons of two items ranges from the maximum value 9 to $1 / 9$ (0.111 in decimal from). Let aij represent the comparison between item-i (left) and item-j (right). If item-i is 5 times (strong importance) more important than item-j for a given criteria or product, then the comparison aji $=1 /$ aij $=1 / 5(0.200)$ or the reciprocal value for the paired comparison between both items.

After the comparison matrix is formed, AHP terminates by computing an eigenvector (also called a priority vector) that represents the relative ranking of importance (or preference) attached to the criteria or objects being compared. The largest eigenvalue provides a measure of consistency. Consistency is a matrix algebraic property of cardinal transitivity where the equality $\mathrm{a}(\mathrm{ij})=1 / \mathrm{a}(\mathrm{ji})=\mathrm{a}(\mathrm{ji})-1$, and $\mathrm{a}(\mathrm{ij})=\mathrm{a}(\mathrm{ik}) \mathrm{a}(\mathrm{kj})$ for any index $\mathrm{i}, \mathrm{j}, \mathrm{k}$. Inconsistencies arise if the transitive property is not satisfied as determined when the largest eigen value from the comparison matrix far exceeds the number of items being compared.

The AHP preference scale shows in Table 2.1 to form the comparison matrices [12].

Table 2.1: Preferences made on 1-9 scale

\begin{tabular}{lcc}
\hline $\begin{array}{l}\text { AHP Scale of Importance } \\
\text { for comparison pair (Aij) }\end{array}$ & Numeric Rating & Reciprocal (decimal) \\
\hline Extreme Importance & 9 & $1 / 9(0.111)$ \\
Very strong to extremely & 8 & $1 / 8(0.125)$ \\
Very strong importance & 7 & $1 / 7(0.143)$ \\
Strongly to very strong & 6 & $1 / 6(0.167)$ \\
Strong Importance & 5 & $1 / 5(0.200)$ \\
Moderately to Strong & 4 & $1 / 4(0.250)$ \\
Moderate Importance & 3 & $1 / 3(0.333)$ \\
Equally to Moderately & 2 & $1.2(0.500)$ \\
Equal Importance & 1 & $1(1.000)$ \\
\hline
\end{tabular}


The Geometric Mean is an alternative measure of the Priority and was formed by taking the $\mathrm{n}$-th root of the product matrix of row elements divided by the column sum of row geometric means. The Geometric Mean agrees closely with the Priority.

Lambdamax (4.2385) is an eigen value scalar that solved the characteristic equation of the input comparison matrix. Ideally, the Lambdamax value should equal the number of factors in the comparison $(\mathrm{n}=4)$ for total consistency.

The consistency index (ci) measures the degree of logical consistency among pair-wise comparisons. The random index (ri) is the average CI value of randomly-generated comparison matrices using Saaty's preference scale (Table 3) sorted by the number of items being considered. If $|\mathrm{CI}|<0.05$, it shows good consistency of pair-wise comparisons. If $|\mathrm{CI}|>0.051$ means the pair-wise comparison should be revised.

$$
\mathrm{CI}=\frac{(\lambda \max -\mathrm{n})}{(\mathrm{n}-1)}
$$

Consistency ratio (cr) indicates the amount of allowed inconsistency ( 0.10 or $10 \%)$. Higher numbers mean the comparisons are less consistent. Smaller numbers mean comparisons are more consistent. CRs above 0.1 means the pair-wise comparison should be revisited or revised.

$$
C R=\frac{|\mathrm{CI}|}{\mathrm{RI}}
$$

Random Index (RI) is the average value of CI for random matrices using the Saaty scale obtained by Forman (Geoff, 2004). To determine the goodness of CI, AHP compares it by Random Index (RI), and the result is what we call Consistency Ratio (CR). Random Index is the Consistency Index of a randomly generated reciprocal matrix from the scale 1 to 9 (Geoff, 2004). Table 2.4 below shows the values R.I. sorted out by order 1 to 15 matrix. The CR can then be calculated.

Table 2. 2: RI index

\begin{tabular}{llllllllllllllll}
\hline $\mathrm{n}=$ & 1 & 2 & 3 & 4 & 5 & 6 & 7 & 8 & 9 & 10 & 11 & 12 & 13 & 14 & 15 \\
$\mathrm{RI}$ & 0.0 & 0.0 & 0.5 & 0.9 & 1.1 & 1.2 & 1.3 & 1.4 & 1.4 & 1.4 & 1.5 & 1.4 & 1.5 & 1.5 & 1.5 \\
$=$ & 0 & 0 & 8 & 0 & 2 & 4 & 2 & 1 & 5 & 9 & 1 & 8 & 6 & 7 & 9 \\
\hline
\end{tabular}




\section{METHODOLOGY}

\subsection{Selection of Banks for the Purpose of the Study}

In this paper expert opinion is collected for the generation of criteria and sub criteria weights through a questionnaire containing fuzzy pair wise comparisons using linguistic terms. Further the alternative Banks are given weights based on the size of the stock market. Ten banks were selected purposively for the purpose of the study. The banks selected for the purpose for the study are traded in Hanoi and Ho Chi Minh City stock markets whose selection of the index set is based on the following criteria, which are referenced from thebanker.com - 500 banking brands in 2014:

1. Company's market capitalization rank in the universe should be less than 500

2. Company's turnover rank in the universe should be less than 500

3. Company's trading frequency should be at least $90 \%$ in the last six months.

4. Company should have a positive Net-worth.

5. A company that comes out with an Initial Public Offering (IPO) will be eligible for inclusion in the index, if it fulfills the normal eligibility criteria for the index for a 3 month period instead of a 6 month period.

The banks selected for the purpose of the study are BIDV, VietinBank, ACB, SacomBank, DAB, HDBank, SeABank, SGB, MBB, and SHB (listed in Table 3.1). Moreover, the author has many friends who are current working in the banking system. The banks are selected to administer survey questionnaires are SGB (Ho Chi Minh City branch); DAB (Ho Chi Minh City branch); and Vietcombank (Ho Chi Minh City branch). Customers who have high frequent bank transactions were also invited to participate in this study. The details about participants who are both experts and customers are listed in Table 3.4. 
Table 3. 1: List of Selected Banks

\begin{tabular}{|c|c|c|}
\hline Code & Full Name & Stock Market \\
\hline BIDV & $\begin{array}{l}\text { Joint Stock Commercial Bank for } \\
\text { Investment and Development of Vietnam }\end{array}$ & http://goo.gl/q4bpQ8 \\
\hline VietinBank & $\begin{array}{l}\text { Vietnam Joint Stock Commercial Bank for } \\
\text { Industry and Trade }\end{array}$ & http://goo.gl/uoAGub \\
\hline $\mathrm{ACB}$ & Asia Commercial Bank & http://goo.gl/E06zxG \\
\hline SacomBank & $\begin{array}{l}\text { Sai GonThuong Tin Commercial Joint } \\
\text { Stock Bank }\end{array}$ & http://goo.gl/0i5gGG \\
\hline DongABank & Dong A Commercial Joint Stock Bank & http://goo.gl/daH42K \\
\hline HDBank & $\begin{array}{l}\text { Ho Chi Minh Development Joint Stock } \\
\text { Commercial Bank }\end{array}$ & http://goo.gl/b93BeJ \\
\hline SeABank & $\begin{array}{l}\text { Southeast Asia Commercial Joint Stock } \\
\text { Bank }\end{array}$ & http://goo.gl/6CJgBR \\
\hline SGB & Saigon Bank for Industry and Trade & http://goo.gl/cn1CKO \\
\hline MBB & Military Commercial Joint Stock Bank & http://goo.gl/QyWCm5 \\
\hline SHB & $\begin{array}{l}\text { Saigon Hanoi Commercial Joint Stock } \\
\text { Bank }\end{array}$ & http://goo.gl/uNuKsS \\
\hline
\end{tabular}

\subsection{Evaluation Criteria and Sub-criteria}

The first step of the proposed model is to determine all the important criteria and their relationship with the decision variables in the form of a hierarchy. This step is crucial because the selected criteria can influence the final choice.

These questions are always raised whenever we have contacts with the people we want to survey on. And these are asked by short interviews. This step is crucial because it can raise that the data used in this study is provided and confirmed by the experts in the field of banking and customers using banking services.

1. Are you an expert in this field, working in it daily?

2. Do you work in this field occasionally?

3. Are you knowledgeable about this field through occasional professional reading?

4. Would you classify yourself as an informed layman?

5. Are you uninformed about this field? 
The first round questionnaire was implemented in November 4th to November 8th 2014. In the first round, the panellists were asked to suggest new or current criteria in the job of ranking banks. Many new suggestions were received. They were asked to review the list below and provide their judgments about their likelihood and impacts in the table 3.2.

Then these factors are arranged into the 5 main criteria including: Income, Expenditure, Staff, Security and ATM services.

Table 3.2: Summary of Parameters to Evaluate Bank Performance

\begin{tabular}{|c|c|c|c|}
\hline Parameters & Weighted average & $\begin{array}{c}\text { Frequency } \\
\text { (Expert) }\end{array}$ & Percentage \\
\hline Safety of funds & 1.50 & 221 & $2.9404 \%$ \\
\hline Secured ATMs & 1.60 & 212 & $2.8206 \%$ \\
\hline ATM availability & 1.61 & 201 & $2.6743 \%$ \\
\hline Reputation & 1.61 & 120 & $1.5966 \%$ \\
\hline Personal attention & 1.65 & 012 & $0.1597 \%$ \\
\hline Pleasing manners & 1.66 & 100 & $1.3305 \%$ \\
\hline Confidentiality & 1.67 & 021 & $0.2794 \%$ \\
\hline Closeness to work & 1.69 & 003 & $0.0399 \%$ \\
\hline Timely service & 1.70 & 321 & $4.2709 \%$ \\
\hline $\begin{array}{c}\text { Friendly staff willing } \\
\text { to help }\end{array}$ & 1.71 & 101 & $1.3438 \%$ \\
\hline Clear communication & 1.74 & 102 & $1.3571 \%$ \\
\hline $\begin{array}{l}\text { Higher rate of Int- } \\
\text { deposits }\end{array}$ & 1.74 & 101 & $1.3438 \%$ \\
\hline Size of the bank & 1.74 & 121 & $1.6099 \%$ \\
\hline Quick/prompt service & 1.75 & 012 & $0.1597 \%$ \\
\hline Minimum waiting time & 1.75 & 101 & $1.3438 \%$ \\
\hline $\begin{array}{l}\text { Convenient working } \\
\text { hour }\end{array}$ & 1.75 & 012 & $0.1597 \%$ \\
\hline More No. of branches & 1.78 & 011 & $0.1464 \%$ \\
\hline
\end{tabular}




\begin{tabular}{|c|c|c|c|}
\hline $\begin{array}{l}\text { Good complaint } \\
\text { handling }\end{array}$ & 1.80 & 101 & $1.3438 \%$ \\
\hline Any branch banking & 1.81 & 013 & $0.1730 \%$ \\
\hline $\begin{array}{c}\text { Modern } \\
\text { looking(building) }\end{array}$ & 1.83 & 013 & $0.1730 \%$ \\
\hline Prompt response & 1.83 & 101 & $1.3438 \%$ \\
\hline $\begin{array}{c}\text { Ease contact branch } \\
\text { manager }\end{array}$ & 1.83 & 104 & $1.3837 \%$ \\
\hline User friendly ATMs & 1.84 & 207 & $2.7541 \%$ \\
\hline Brand name & 1.84 & 011 & $0.1464 \%$ \\
\hline Interest Expenditure & 1.85 & 301 & $4.0048 \%$ \\
\hline $\begin{array}{c}\text { Connectivity to other } \\
\text { bank's ATMs }\end{array}$ & 1.87 & 344 & $4.5769 \%$ \\
\hline $\begin{array}{c}\text { Accuracy/absence of } \\
\text { errors }\end{array}$ & 1.89 & 344 & $4.5769 \%$ \\
\hline $\begin{array}{c}\text { No breakdown of } \\
\text { machine }\end{array}$ & 1.90 & 011 & $0.1464 \%$ \\
\hline Closeness to home & 1.90 & 001 & $0.0133 \%$ \\
\hline $\begin{array}{c}\text { Delivering what is } \\
\text { promised }\end{array}$ & 1.90 & 015 & $0.1996 \%$ \\
\hline Dependability & 1.90 & 025 & $0.3326 \%$ \\
\hline $\begin{array}{l}\text { Secured internet } \\
\text { banking }\end{array}$ & 1.98 & 358 & $4.7632 \%$ \\
\hline $\begin{array}{c}\text { Employees dress \& } \\
\text { appearance }\end{array}$ & 2.01 & 012 & $0.1597 \%$ \\
\hline $\begin{array}{l}\text { User friendly net } \\
\text { banking }\end{array}$ & 2.03 & 106 & $1.4103 \%$ \\
\hline Salary account & 2.04 & 014 & $0.1863 \%$ \\
\hline Easy connectivity & 2.05 & 296 & $3.9383 \%$ \\
\hline $\begin{array}{l}\text { Higher rate of Int- } \\
\text { loans }\end{array}$ & 2.06 & 014 & $0.1863 \%$ \\
\hline
\end{tabular}




\begin{tabular}{|c|c|c|c|}
\hline Other Income & 2.07 & 345 & $4.5902 \%$ \\
\hline Debit card & 2.09 & 104 & $1.3837 \%$ \\
\hline $\begin{array}{l}\text { Low/reasonable } \\
\text { service-charges }\end{array}$ & 2.10 & 044 & $0.5854 \%$ \\
\hline Advertisement & 2.11 & 042 & $0.5588 \%$ \\
\hline Investment & 2.11 & 258 & $3.4327 \%$ \\
\hline Staff knowledge & 2.12 & 268 & $3.5657 \%$ \\
\hline Innovative services & 2.14 & 355 & $4.7233 \%$ \\
\hline Error free net banking & 2.16 & 011 & $0.1464 \%$ \\
\hline Advances & 2.17 & 233 & $3.1001 \%$ \\
\hline Internet banking & 2.18 & 100 & $1.3305 \%$ \\
\hline Businesses/Employee & 2.20 & 333 & $4.4305 \%$ \\
\hline Depository services & 2.22 & 053 & $0.7052 \%$ \\
\hline Phone banking & 2.25 & 044 & $0.5854 \%$ \\
\hline Profit/EMPLOYEE & 2.26 & 257 & $3.4194 \%$ \\
\hline Credit card & 2.30 & 035 & $0.4657 \%$ \\
\hline One stop banking & 2.33 & 111 & $1.4768 \%$ \\
\hline Operating Expenditure & 2.33 & 333 & $4.4305 \%$ \\
\hline Other it based services & 2.44 & 014 & $0.1863 \%$ \\
\hline Interest Income & 2.53 & 385 & $5.1224 \%$ \\
\hline Friend's referral & 2.61 & 014 & $0.1863 \%$ \\
\hline My father's bank & 2.62 & 014 & $0.1863 \%$ \\
\hline
\end{tabular}

After we have 5 main criteria, the experts were asked to list down sub-criteria of each main criterion. This process is called second round selection, which are listed in the following tables. This process will be taken placed right after we summarized the main criteria, which was during the period of 13 November to 16 November, 2014. Moreover, they are also asked to fulfil one more point before we go the survey of AHP to do the ranking of the field. From table 3.13, the author takes only the parameters which are evaluated by experts and its frequency of important about more 2\%. Table 3.3 lists 19 parameters which are more important and used in this study. This process is important, so that the author has seriously 
considered to be used in the AHP method. These 19 parameters are put into 5 main criteria, which are also by survey experts and mentioned earlier.

Table 3.3: 19 Main Parameters

\begin{tabular}{|c|c|c|c|}
\hline Parameters & Weighted average & $\begin{array}{l}\text { Frequency } \\
\text { (Expert) }\end{array}$ & Percentage \\
\hline Safety of funds & 1.50 & 221 & $2.9404 \%$ \\
\hline Secured ATMs & 1.60 & 212 & $2.8206 \%$ \\
\hline ATM availability & 1.61 & 201 & $2.6743 \%$ \\
\hline Timely service & 1.70 & 321 & $4.2709 \%$ \\
\hline User friendly ATMs & 1.84 & 207 & $2.7541 \%$ \\
\hline Interest Expenditure & 1.85 & 301 & $4.0048 \%$ \\
\hline $\begin{array}{c}\text { Connectivity to other } \\
\text { bank's ATMs }\end{array}$ & 1.87 & 344 & $4.5769 \%$ \\
\hline $\begin{array}{c}\text { Accuracy/absence of } \\
\text { errors }\end{array}$ & 1.89 & 344 & $4.5769 \%$ \\
\hline $\begin{array}{l}\text { Secured internet } \\
\text { banking }\end{array}$ & 1.98 & 358 & $4.7632 \%$ \\
\hline Easy connectivity & 2.05 & 296 & $3.9383 \%$ \\
\hline Other Income & 2.07 & 345 & $4.5902 \%$ \\
\hline Investment & 2.11 & 258 & $3.4327 \%$ \\
\hline Staff knowledge & 2.12 & 268 & $3.5657 \%$ \\
\hline Innovative services & 2.14 & 355 & $4.7233 \%$ \\
\hline Advances & 2.17 & 233 & $3.1001 \%$ \\
\hline $\begin{array}{c}\text { Businesses per } \\
\text { Employee }\end{array}$ & 2.20 & 333 & $4.4305 \%$ \\
\hline Profit per EMPLOYEE & 2.26 & 257 & $3.4194 \%$ \\
\hline Operating Expenditure & 2.33 & 333 & $4.4305 \%$ \\
\hline Interest Income & 2.53 & 385 & $5.1224 \%$ \\
\hline
\end{tabular}


The hierarchy is structured from the top (the overall goal of the problem) through the intermediate levels (criteria and sub-criteria on which subsequent levels depend) to the bottom level (the list of alternatives). The structure of the above-mentioned hierarchy is given in Figure 3.1. Figure 3.1 just summarizes and visualizes what have mentioned. We have here 5 main criteria, 19 sub-criteria and 10 alternatives i.e. banking brands.

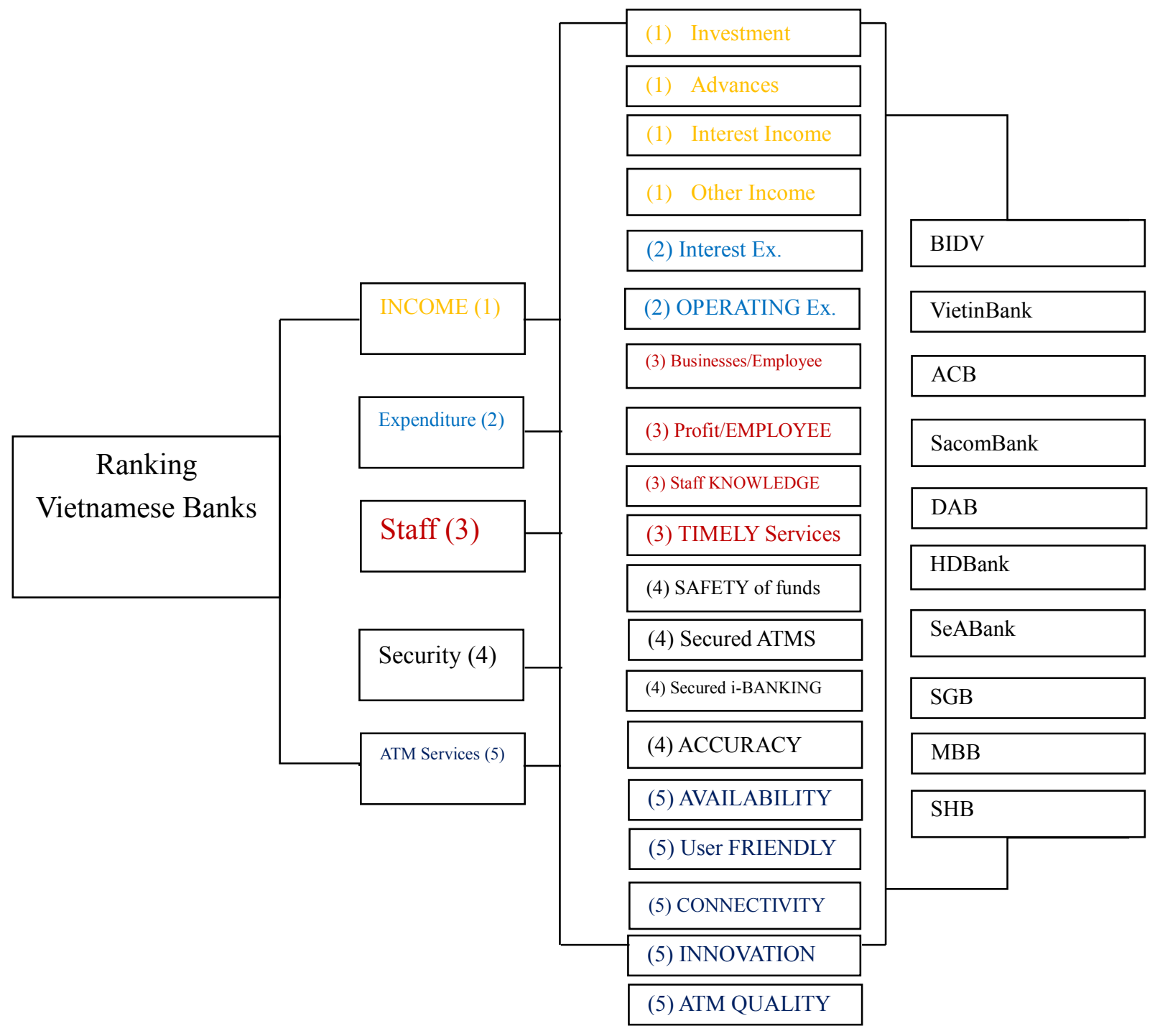

Figure 3.1: Research Hierarchy 
Table 3.4: Descriptions of Participants into Selecting Research Elements

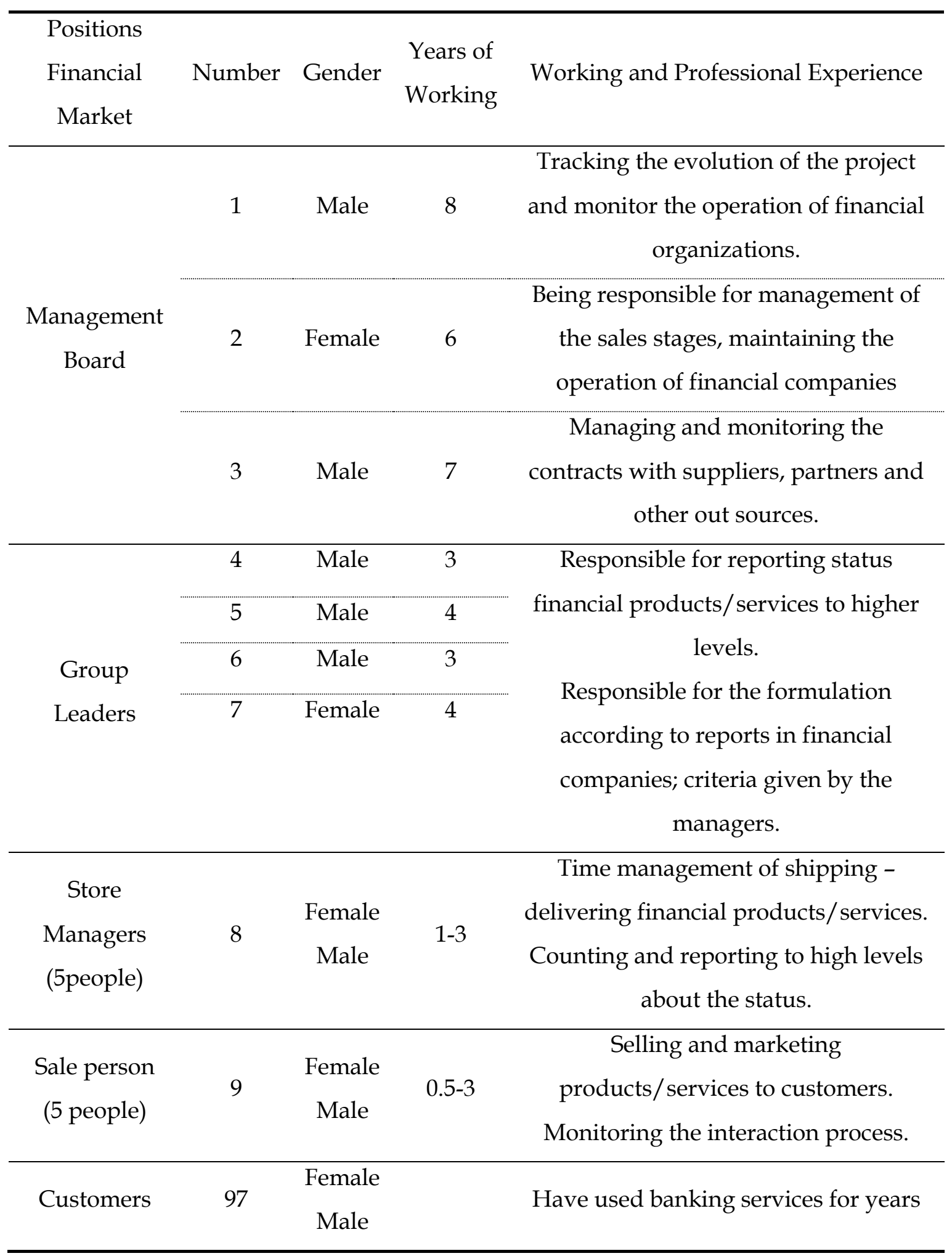


These experts are working in the financial organizations e.g., Prudential; Bao Viet Insurance, AIA Vietnam etc. They are all anonymous in this study. Customers are described to use the banking services for years. They are employees in organizations in Hanoi City. They are the researchers' friends and are willing to participate in this study. These organizations have the connection with banks in this study. They have the salary paying interactions by months.

\subsection{The Process to Select the Right Target of the AHP Method}

This section presents the process according to the method of calculation process of AHP. Start with a hierarchical diagram level 5 main criteria governing the evaluation of the bank industry (see figure 3.1). This matrix shows the relationship between the main criteria according to the scale of the AHP. Based on this table can determine the correlation between the level of importance of the variables.

The whole process of this study is present in figure 3.2. There are 9 phases to run, select and analysis based on the applied method - AHP.

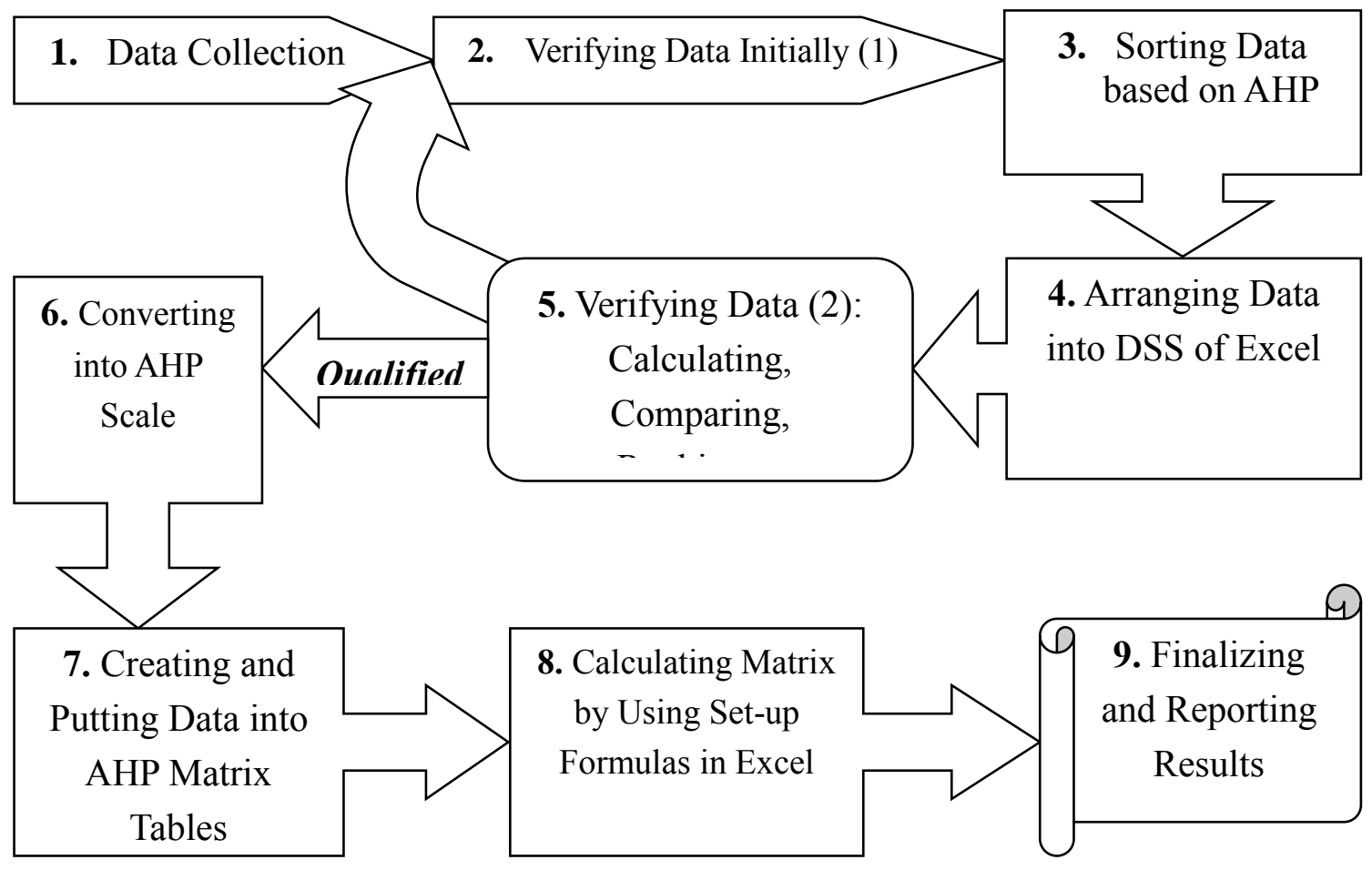

Figure 3.2: Flowchart of Phases to Carry Research 


\section{Phase 1: data collection}

Delphi method: 1st round (14-18th November, 2014); 2nd round (13-16 December, 2014) AHP questionnaire: 18-25th January, 2015

The process of data collection is carried out according to the method of experts:

Step 1: based on assessment model has been developed, author use pilot interviews to experts to verify the appropriateness of the 6 main criteria KPI in level one and 16 in level two, together with confirming the identification actual business reality.

Step 2: based on the results of step 1 to adjust the model and building surveys/questionnaires.

Step 3: surveys combined with direct interviews to each expert. At the request should have over 30 experts but by the actual situation should be reduced to 26experts. Moreover, customers who have used banking services for years are also involved in this study.

Step 4: collect other data through reports and documents related

\section{Phase 2: a batch process data}

After collecting a full range of primary data through surveys and interviews with experts' opinions, together with the secondary data through reports: financial, production, performance, etc., these data are processed through the steps of a batch filtering criteria of the main criteria, then filter by the KPI side, verify authenticity versus reality and reliability of the data.

\section{Phase 3: sorting data and KPI main criteria of the model}

A batch is classified according to six main criteria, and then they are further classified according to $16 \mathrm{KPI}$ sub-criteria of the model

\section{Phase 4: enter the model created by Excel}

Excel is as a DSS generator: it is used to construct the computational model,and to handle data for each KPI fitting main criteria in the evaluation model. After setup is complete, the DSS model is to conduct verification of scale, the formula to ensure the appropriateness and scientific. Then, we enter the processed and classified data prior to the DSS model to prepare for phase 5 . 


\section{Phase 5: data processing secondly}

After entering the data, we conducted calculations, check, and then evaluate for each scale suitably.

\section{Phase 6: scale transition to AHP}

AHP method using pair wise comparison scale separately on a scale from one to nine, so after the calculation results ranking suppliers, we must make the transition scales corresponding to the AHP under the own standards of this method. This stage aims to prepare for entering data into the matrix of pair wise comparison at a later stage.

\section{Phase 7: Creating and Putting Data into AHP matrix table}

The first boot after the application of the AHP hierarchy drawing assessment model, enter the criteria in a level floor, then to the sub-criteria floor level to level two to $n$, and finally enter choice alternatives. Then enter the data were processed in each pair wise comparison matrices, respectively. Inside is under processing data has been entered into the pair wise comparison matrix between the six main criteria in the evaluation model.

\section{Phase 8: Calculating Matrix by Using Set-up Formulas in Excel}

After we have the AHP tables, we use Excel as a tool to calculate these matrices. Inputting all the data surveyed is a careful step to do to make sure that the calculation is accurate.

\section{Phase 9: Finalizing and Reporting Results}

This is the final step of the process. We just see and report results. This will be illustrated carefully in chapter 4 .

Once the hierarchy is established, the fuzzy pair wise comparison takes place. The experts compare all the criteria on the same level of the hierarchy. A pair wise comparison is performed by using Fuzzy linguistic terms in the scale of $0-10$ described by the Triangular Fuzzy Numbers in the Table 1.1. In Buckley's method, the element of the negative judgment is treated as an inverse and reversed order of the fuzzy number of the corresponding positive judgment. Thus it requires not only a rigorous manipulation in the construction of reciprocal matrix but also due to transitivity the result becomes inconsistent. Again to reflect pessimistic, most likely and optimistic decision making environment, triangular fuzzy numbers with minimum value, most plausible value \& maximum value are considered. 


$$
A=\left(\begin{array}{ccc}
1 & a_{12} & a_{1 n} \\
a_{21} & 1 & a_{2 n} \\
a_{31} & a_{32} & a_{3 n}
\end{array}\right)
$$

To simplify the calculation of element weight the fuzzy pair wise comparison matrix is broken into crisp matrices where the crisp matrices are formed by taking the minimum values, most plausible values \& maximum values from the triangular fuzzy numbers, which were mentioned in chapter 2.

\section{RESULTS}

\subsection{Setting Stage}

In this chapter, the whole process of calculation will be analyzed. Then the results of each weight of the alternatives will be illustrated. And finally, the final results of selection the right instant coffee supplier will be displayed according to experts' interview.

Comparable data are collected by the method of survey experts through interviews and direct the relevant agencies. Homogeneity index (incon) 0.05 of AHP is satisfactory. The main criteria are comparable bond correlation pairs separate to produce detailed data calculations. The tables above are typical illustrations for pair wised comparison matrices need to enter the data set gathered from interviews of experts in the relevant industry. There are 23 matrices developed to cater for the processing of the data model. And following authors quote a matrix in which to further illustrate this problem.

$$
\begin{gathered}
\text { Denoting: Income - IC } \\
\text { Expenditure - Exp } \\
\text { Staff - St } \\
\text { Security - Sec } \\
\text { ATM Service - ATM }
\end{gathered}
$$


Table 4.1: Matrix of Pair Wise Comparison

\begin{tabular}{cccccc}
\hline Criteria & IC & Exp & St & Sec & ATM \\
\hline IC & 1.0110 & 2.00000 & 2.00000 & 2.00000 & 4.00000 \\
Exp & 0.50 & 1.00 & 1.00000 & 0.20000 & 2.00000 \\
St & 0.50 & 1.00 & 1.00 & 0.33333 & 1.00000 \\
Sec & 0.50 & 5.00 & 3.00 & 1.00 & 4.00000 \\
ATM & 0.25 & 0.50 & 1.00 & 0.25 & 1.00 \\
Total & 2.7500 & 9.50 & 8.00 & 3.7833 & 12.00 \\
\hline
\end{tabular}

Table 4.1 gives a typical example of how to input interviewed data into the matrix of AHP. For example, Income is 2 times important than Expenditure, then Expenditure is equal 0.5 of Income.

Table 4.2: Results of first Phase Calculation

\begin{tabular}{ccccccc}
\hline Criteria & IC & Exp & St & Sec & ATM & Weight \\
\hline IC & 0.3636 & 0.2105 & 0.2500 & 0.5286 & 0.3333 & $\mathbf{3 3 . 7 \%}$ \\
Exp & 0.1818 & 0.1053 & 0.1250 & 0.0529 & 0.1667 & $\mathbf{1 2 . 6 \%}$ \\
St & 0.1818 & 0.1053 & 0.1250 & 0.0881 & 0.0833 & $\mathbf{1 1 . 7 \%}$ \\
Sec & 0.1818 & 0.5263 & 0.3750 & 0.2643 & 0.3333 & $\mathbf{3 3 . 6 \%}$ \\
ATM & 0.0909 & 0.0526 & 0.1250 & 0.0661 & 0.0833 & $\mathbf{8 . 4 \%}$ \\
Total & 1 & 1 & 1 & 1 & 1 & $100 \%$ \\
\hline
\end{tabular}

After doing calculation from table 4.1, each cell is done by choice divided to the cell total value of the matrix. For example, we have $0.3243=1 / 3.0833$. Then, the weight is the average of each row, which is total divided to the number of criteria.

This weight will be used to calculated the second phase of the matrix, which is illustrated in the below table. 
Table 4.3: Results of Second phase calculation

\begin{tabular}{cccccccc}
\hline Criteria & IC & Exp & St & Sec & ATM & SUM & SUM/Weight \\
\hline IC & 0.3372 & 0.2526 & 0.2334 & 0.6723 & 0.3344 & 1.83 & 5.43 \\
Exp & 0.1686 & 0.1263 & 0.1167 & 0.0672 & 0.1672 & 0.65 & 5.11 \\
St & 0.1686 & 0.1263 & 0.1167 & 0.1121 & 0.0836 & 0.61 & 5.20 \\
Sec & 0.1686 & 0.6316 & 0.3501 & 0.3362 & 0.3344 & 1.82 & 5.42 \\
ATM & 0.0843 & 0.0632 & 0.1167 & 0.0840 & 0.0836 & 0.43 & 5.17 \\
Total & 0.93 & 1.20 & 0.93 & 1.27 & 1.00 & 5.34 & 26.33 \\
Average & 0.19 & 0.24 & 0.19 & 0.25 & 0.20 & 1.067 & 5.27 \\
\hline
\end{tabular}

From table 4.1 and table 4.3, we have each criterion value calculation. Then, we come up with SUM and SUM/weight. SUM/Weight is an important element to calculation lambda max and $\mathbf{C I}$ with $\mathbf{C R}$ factors, which then are used to test the consistency of the matrix and calculation.

$$
\begin{aligned}
& \lambda \max =\sum \frac{\frac{\text { SUM }}{\text { Weight }}}{n}=\frac{26.33}{5}=5.27 \\
& C I=\frac{\lambda \max -n}{n-1}=\frac{5.27-5}{5}=0.066
\end{aligned}
$$

$\mathrm{CI}=0.066<0.05$, it shows good consistency of pair-wise comparisons.

$$
\mathrm{CR}=\frac{|\mathrm{CI}|}{\mathrm{RI}}=\frac{0.066}{1.12}=0.059
$$

As mentioned in chapter 2 , there are 6 criteria so $\mathrm{RI}=1.12$.

$\mathrm{CR}=0.059=5.9 \%<10 \%$, that means consistent.

Table 4.4: Results from Matrix of Sub-criteria under Income

\begin{tabular}{cccccc}
\hline Income & & & Interest & Other & Weight \\
& Investment & Advances & Income & Income & \\
\hline Investment & 0.7039 & 0.8077 & 0.6316 & 0.5000 & $\mathbf{6 6 . 1 \%}$ \\
Advances & 0.1006 & 0.1154 & 0.2105 & 0.3333 & $\mathbf{1 9 . 0 \%}$ \\
Interest Income & 0.1173 & 0.0577 & 0.1053 & 0.1111 & $\mathbf{9 . 8 \%}$ \\
Other Income & 0.0782 & 0.0192 & 0.0526 & 0.0556 & $\mathbf{5 . 1 \%}$ \\
Total & 1 & 1 & 1 & 1 & $\mathbf{1 0 0 \%}$ \\
\hline
\end{tabular}


$\mathrm{CR}=0.083=8.3 \%<10 \%$, that means consistent.

From table 4.3, we have the weight of Income is $33.7 \%$ over $100 \%$ of 5 main criteria (1-level). Then, we have the weight of each sub-criterion from table 4.4. Here, we come to the table showing the percentage of sub-criterion over the whole picture to choose the supplier.

Table 4. 5: The Global Percentage of each Sub-criterion under Income

\begin{tabular}{cccc}
\hline Income & Weight (Local) & Weight of FC & $\begin{array}{c}\text { Weight of sub- } \\
\text { criterion (Global) }\end{array}$ \\
\hline Investment & $\mathbf{6 6 . 1 \%}$ & $33.7 \%$ & $22.27 \%$ \\
Advances & $\mathbf{1 9 . 0 \%}$ & $33.7 \%$ & $6.40 \%$ \\
Interest Income & $\mathbf{9 . 8} \%$ & $33.7 \%$ & $3.30 \%$ \\
Other Income & $\mathbf{5 . 1 \%}$ & $33.7 \%$ & $1.73 \%$ \\
Total & $\mathbf{1 0 0} \%$ & -- & $\mathbf{3 3 . 7 \%}$ \\
\hline
\end{tabular}


Table 4.6: Results from Matrix of the Alternatives under Sub-criterion -- Investment

\begin{tabular}{cccccccccccc}
\hline $\begin{array}{c}\text { Sub-criterion } \\
\text { (Investment) }\end{array}$ & BIDV & VietinBank & ACB & SacomBank & DAB & HDBank & SeABank & SGB & MBB & SHB & Weight \\
\hline BIDV & 0.0727 & 0.0643 & 0.2130 & 0.1094 & 0.1541 & 0.0317 & 0.02 & 0.10 & 0.14 & 0.06 & $\mathbf{9 . 6 \%}$ \\
VietinBank & 0.0364 & 0.0322 & 0.0106 & 0.0122 & 0.0110 & 0.1270 & 0.26 & 0.05 & 0.18 & 0.01 & $\mathbf{7 . 4 \%}$ \\
ACB & 0.0182 & 0.1609 & 0.0532 & 0.0219 & 0.0193 & 0.1905 & 0.18 & 0.21 & 0.09 & 0.02 & $\mathbf{9 . 6 \%}$ \\
SacomBank & 0.0727 & 0.2895 & 0.2662 & 0.1094 & 0.1541 & 0.2540 & 0.02 & 0.10 & 0.14 & 0.22 & $\mathbf{1 6 . 3} \%$ \\
DAB & 0.0364 & 0.2252 & 0.2130 & 0.0547 & 0.0771 & 0.1905 & 0.03 & 0.03 & 0.02 & 0.22 & $\mathbf{1 1 . 0} \%$ \\
HDBank & 0.1455 & 0.0161 & 0.0177 & 0.0273 & 0.0257 & 0.0635 & 0.18 & 0.21 & 0.09 & 0.06 & $\mathbf{8 . 3} \%$ \\
SeABank & 0.29 & 0.01 & 0.03 & 0.55 & 0.23 & 0.03 & 0.09 & 0.21 & 0.14 & 0.03 & $\mathbf{1 6 . 0} \%$ \\
SGB & 0.04 & 0.03 & 0.01 & 0.05 & 0.15 & 0.02 & 0.02 & 0.05 & 0.14 & 0.17 & $\mathbf{6 . 8 \%}$ \\
MBB & 0.07 & 0.01 & 0.03 & 0.04 & 0.15 & 0.03 & 0.03 & 0.02 & 0.05 & 0.17 & $\mathbf{5 . 9 \%} \%$ \\
SHB & 0.22 & 0.16 & 0.16 & 0.03 & 0.02 & 0.06 & 0.18 & 0.02 & 0.02 & 0.06 & $\mathbf{9 . 1} \%$ \\
Total & 1 & 1 & 1 & 1 & 1 & 1 & 1 & 1 & 1 & 1 & $\mathbf{1 0 0} \%$ \\
\hline
\end{tabular}


$\mathrm{CR}=0.083=8.3 \%<10 \%$, that means consistent.

With the same process, from tables 4.5 and 4.6 we can calculate the whole percentage of choice for each supplier under each sub-criterion, which are Investment (22.27\%); Advances: 6.4\%; Interest Income: 3.3\%; and Other Income: 1.73\%

Table 4.7: Global Percentage of each Supplier under Investment of INCOME

\begin{tabular}{cccc}
\hline $\begin{array}{c}\text { Sub-criterion } \\
\text { (Investment) }\end{array}$ & $\begin{array}{c}\text { Weight } \\
\text { (Local) }\end{array}$ & $\begin{array}{c}\text { Weight of sub- } \\
\text { criterion } \\
\text { (Investment) }\end{array}$ & $\begin{array}{c}\text { Weight of Supplier } \\
\text { (Global) }\end{array}$ \\
\hline BIDV & $\mathbf{9 . 6 \%}$ & $22.27 \%$ & $2.15 \%$ \\
VietinBank & $\mathbf{7 . 4 \%}$ & $22.27 \%$ & $1.65 \%$ \\
ACB & $\mathbf{9 . 6 \%}$ & $22.27 \%$ & $2.13 \%$ \\
SacomBank & $\mathbf{1 6 . 3} \%$ & $22.27 \%$ & $3.62 \%$ \\
DAB & $\mathbf{1 1 . 0} \%$ & $22.27 \%$ & $2.44 \%$ \\
HDBank & $\mathbf{8 . 3 \%}$ & $22.27 \%$ & $1.84 \%$ \\
SeABank & $\mathbf{1 6 . 0} \%$ & $22.27 \%$ & $3.56 \%$ \\
SGB & $\mathbf{6 . 8} \%$ & $22.27 \%$ & $1.52 \%$ \\
MBB & $\mathbf{5 . 9} \%$ & $22.27 \%$ & $1.31 \%$ \\
SHB & $\mathbf{9 . 1} \%$ & $22.27 \%$ & $2.03 \%$ \\
Total & $\mathbf{1 0 0} \%$ & -- & $22.27 \%$ \\
\hline
\end{tabular}

These are examples what thesis does and gets to have the data from interviews, and surveys of experts.

\subsection{Results and Analyses five Suppliers by each Criterion}

As mentioned earlier, the steps to calculate by apply AHP which are from the main criteria to all the alternatives. Table 4.8 just summarizes the results of the 1 step which is the weights of main criteria.

Table 4.8: Main Criteria Weights

\begin{tabular}{|c|c|c|c|}
\hline Main Criteria & SUM & SUM/Weight & Global Weight \\
\hline IC & 1.83 & 5.43 & $\mathbf{3 3 . 7 \%}$ \\
\hline Exp & 0.65 & 5.11 & $\mathbf{1 2 . 6} \%$ \\
\hline St & 0.61 & 5.20 & $\mathbf{1 1 . 7 \%}$ \\
\hline Sec & 1.82 & 5.42 & $\mathbf{3 3 . 6} \%$ \\
\hline ATM & 0.43 & 5.17 & $\mathbf{8 . 4 \%}$ \\
\hline
\end{tabular}


According experts and customers surveyed in this study, the INCOMES and SECURITY of the bank are the highly important factors at $33.7 \%$ and $33.6 \%$. ATM services are at lowest percentage (8.4\%). This will be discussed in the chapter 5 in which the author would like to make conclusions and research suggestions.

Under their main criteria, the sub-criteria are calculated their global weights. For example, the main criteria of INVESTMENT is INCOME (at 33.7\%) and the INVESTMENT local weight is at $66.1 \%$ so its global weight is $22.7 \%(=66.1 \% * 33.7 \%)$.

Table 4.9: Sub-criteria Weights

\begin{tabular}{|c|c|c|c|c|c|}
\hline Sub-criteria & SUM & SUM/WEIGHT & $\begin{array}{c}\text { Local } \\
\text { Weights }\end{array}$ & $\begin{array}{c}\text { Main } \\
\text { Criteria }\end{array}$ & $\begin{array}{c}\text { Global } \\
\text { Weights }\end{array}$ \\
\hline Investment & 3.04 & 4.60 & $66.1 \%$ & $\begin{array}{c}\text { Income } \\
33.7 \%\end{array}$ & $22.27 \%$ \\
\hline Advances & 0.79 & 4.15 & $19.0 \%$ & & $6.40 \%$ \\
\hline Interest Income & 0.41 & 4.15 & $9.8 \%$ & & $3.30 \%$ \\
\hline Other Income & 0.21 & 4.00 & $5.1 \%$ & & $1.73 \%$ \\
\hline Interest Ex. & 1.33 & 2.00 & $66.7 \%$ & $\begin{array}{c}\text { Expenditure } \\
12.6 \%\end{array}$ & $8.40 \%$ \\
\hline Operating Ex. & 0.67 & 2.00 & $33.3 \%$ & & $4.20 \%$ \\
\hline Biz/Employee & 0.89 & 4.17 & $21.4 \%$ & $\begin{array}{l}\text { Staff } \\
11.7 \%\end{array}$ & $2.51 \%$ \\
\hline Profit/Employee & 0.63 & 4.27 & $14.9 \%$ & & $1.74 \%$ \\
\hline Staff Knowledge & 0.52 & 4.11 & $12.6 \%$ & & $1.47 \%$ \\
\hline Timely Service & 2.16 & 4.23 & $51.2 \%$ & & $5.99 \%$ \\
\hline Safety of Funds & 1.53 & 4.16 & $36.8 \%$ & $\begin{array}{c}\text { Security } \\
33.6 \%\end{array}$ & $12.36 \%$ \\
\hline Secured ATMs & 0.75 & 4.10 & $18.4 \%$ & & $6.19 \%$ \\
\hline $\begin{array}{l}\text { Secured i- } \\
\text { Banking }\end{array}$ & 1.16 & 4.09 & $28.5 \%$ & & $9.56 \%$ \\
\hline Accuracy & 0.67 & 4.13 & $16.3 \%$ & & $5.48 \%$ \\
\hline Availability & 0.52 & 5.10 & $10.1 \%$ & $\begin{array}{l}\text { ATM } \\
8.4 \%\end{array}$ & $0.85 \%$ \\
\hline User friendly & 0.80 & 5.13 & $15.6 \%$ & & $1.31 \%$ \\
\hline Connectivity & 1.98 & 5.40 & $36.6 \%$ & & $3.08 \%$ \\
\hline Innovation & 1.25 & 5.18 & $24.1 \%$ & & $2.03 \%$ \\
\hline ATM Quality & 0.70 & 5.14 & $13.6 \%$ & & $1.14 \%$ \\
\hline
\end{tabular}

The sub-criteria are very important to calculate out the evaluations then rankings, which are mentioned in later parts. 
Table 4.10: Summary of Evaluation Process

\begin{tabular}{|c|c|c|c|c|c|c|c|c|c|c|}
\hline & BIDV & VietinBank & ACB & SacomBank & DAB & HDBank & SeABank & SGB & MBB & SHB \\
\hline Investment (22.7\%) & $2.11 \%$ & $1.77 \%$ & $2.98 \%$ & $1.97 \%$ & $3.13 \%$ & $1.88 \%$ & $2.87 \%$ & $1.66 \%$ & $1.46 \%$ & $2.44 \%$ \\
\hline Advances $(6.40 \%)$ & $0.47 \%$ & $0.67 \%$ & $0.82 \%$ & $0.70 \%$ & $0.88 \%$ & $0.50 \%$ & $0.87 \%$ & $0.44 \%$ & $0.37 \%$ & $0.67 \%$ \\
\hline $\begin{array}{ll}\text { Interest } & \text { Income } \\
(3.30 \%) & \end{array}$ & $0.31 \%$ & $0.36 \%$ & $0.31 \%$ & $0.45 \%$ & $0.41 \%$ & $0.26 \%$ & $0.49 \%$ & $0.23 \%$ & $0.19 \%$ & $0.30 \%$ \\
\hline Other Income $(1.73 \%)$ & $0.21 \%$ & $0.15 \%$ & $0.16 \%$ & $0.19 \%$ & $0.27 \%$ & $0.14 \%$ & $0.23 \%$ & $0.14 \%$ & $0.10 \%$ & $0.14 \%$ \\
\hline Interest Ex. $(8.40 \%)$ & $1.09 \%$ & $1.12 \%$ & $0.93 \%$ & $0.91 \%$ & $1.21 \%$ & $0.55 \%$ & $0.91 \%$ & $0.66 \%$ & $0.48 \%$ & $0.55 \%$ \\
\hline Operating Ex. (4.20\%) & $0.44 \%$ & $0.41 \%$ & $0.62 \%$ & $0.47 \%$ & $0.44 \%$ & $0.27 \%$ & $0.35 \%$ & $0.43 \%$ & $0.36 \%$ & $0.41 \%$ \\
\hline Biz/Employee (2.51\%) & $0.27 \%$ & $0.17 \%$ & $0.24 \%$ & $0.29 \%$ & $0.37 \%$ & $0.21 \%$ & $0.29 \%$ & $0.24 \%$ & $0.24 \%$ & $0.19 \%$ \\
\hline $\begin{array}{l}\text { Profit/Employee } \\
(1.74 \%)\end{array}$ & $0.16 \%$ & $0.14 \%$ & $0.19 \%$ & $0.15 \%$ & $0.26 \%$ & $0.20 \%$ & $0.21 \%$ & $0.15 \%$ & $0.12 \%$ & $0.16 \%$ \\
\hline $\begin{array}{ll}\text { Staff } & \text { Knowledge } \\
(1.47 \%) & \end{array}$ & $0.14 \%$ & $0.13 \%$ & $0.16 \%$ & $0.15 \%$ & $0.14 \%$ & $0.14 \%$ & $0.13 \%$ & $0.12 \%$ & $0.17 \%$ & $0.19 \%$ \\
\hline Timely Service (5.99\%) & $0.60 \%$ & $0.58 \%$ & $0.76 \%$ & $0.82 \%$ & $0.55 \%$ & $0.51 \%$ & $0.64 \%$ & $0.41 \%$ & $0.45 \%$ & $0.66 \%$ \\
\hline $\begin{array}{l}\text { Safety of Funds } \\
(12.36 \%)\end{array}$ & $1.25 \%$ & $1.13 \%$ & $1.97 \%$ & $1.43 \%$ & $1.26 \%$ & $1.09 \%$ & $1.09 \%$ & $0.80 \%$ & $1.25 \%$ & $1.10 \%$ \\
\hline Secured ATMs (6.19\%) & $0.79 \%$ & $0.37 \%$ & $0.63 \%$ & $0.59 \%$ & $0.80 \%$ & $0.55 \%$ & $0.93 \%$ & $0.44 \%$ & $0.55 \%$ & $0.53 \%$ \\
\hline $\begin{array}{l}\text { Secured i-Banking } \\
(9.56 \%)\end{array}$ & $0.98 \%$ & $0.94 \%$ & $1.68 \%$ & $1.09 \%$ & $0.85 \%$ & $0.84 \%$ & $1.01 \%$ & $0.72 \%$ & $0.52 \%$ & $0.92 \%$ \\
\hline
\end{tabular}




\begin{tabular}{|c|c|c|c|c|c|c|c|c|c|c|}
\hline Accuracy (5.48\%) & $0.53 \%$ & $0.56 \%$ & $0.64 \%$ & $0.64 \%$ & $0.51 \%$ & $0.50 \%$ & $0.48 \%$ & $0.35 \%$ & $0.63 \%$ & $0.63 \%$ \\
\hline Availability (0.85\%) & $0.11 \%$ & $0.07 \%$ & $0.08 \%$ & $0.09 \%$ & $0.10 \%$ & $0.07 \%$ & $0.11 \%$ & $0.05 \%$ & $0.08 \%$ & $0.07 \%$ \\
\hline User friendly $(1.31 \%)$ & $0.17 \%$ & $0.09 \%$ & $0.12 \%$ & $0.13 \%$ & $0.15 \%$ & $0.12 \%$ & $0.19 \%$ & $0.11 \%$ & $0.11 \%$ & $0.12 \%$ \\
\hline Connectivity $(3.08 \%)$ & $0.38 \%$ & $0.27 \%$ & $0.29 \%$ & $0.33 \%$ & $0.48 \%$ & $0.25 \%$ & $0.41 \%$ & $0.24 \%$ & $0.18 \%$ & $0.25 \%$ \\
\hline Innovation (2.03\%) & $0.24 \%$ & $0.22 \%$ & $0.25 \%$ & $0.22 \%$ & $0.19 \%$ & $0.18 \%$ & $0.21 \%$ & $0.13 \%$ & $0.18 \%$ & $0.21 \%$ \\
\hline ATM Quality (1.14\%) & $0.13 \%$ & $0.14 \%$ & $0.15 \%$ & $0.12 \%$ & $0.11 \%$ & $0.09 \%$ & $0.12 \%$ & $0.09 \%$ & $0.08 \%$ & $0.12 \%$ \\
\hline Total & $10.38 \%$ & $9.29 \%$ & $12.98 \%$ & $10.74 \%$ & $12.11 \%$ & $8.35 \%$ & $11.54 \%$ & $7.41 \%$ & $7.52 \%$ & $9.66 \%$ \\
\hline
\end{tabular}




\subsection{The Final Rankings}

After respectively calculating, analysis and evaluating of suppliers through each subcriterion of six main criteria in Balanced Scorecard of AHP model, we have been solving the second floor of AHP hierarchy. And this is the final calculation results which are obtained after running the data through the two floors of the criteria assessment model according to the method of AHP. The percentages are of banks shown in the table. Based on these values, we can rank as well as further analysis of the selected alternatives. Plus we can evaluate each bank. Besides, to compare the degree of difference between the alternatives, any financial organizations can make a decision in choosing the best suppliers and the most suitable.

Table 4. 10: The Final Rankings

\begin{tabular}{|c|c|c|}
\hline Ranking & Banks & Global Weight \\
\hline $\mathbf{1}$ & ACB & $12.98 \%$ \\
\hline $\mathbf{2}$ & DAB & $12.11 \%$ \\
\hline $\mathbf{3}$ & SeABank & $11.54 \%$ \\
\hline $\mathbf{4}$ & SacomBank & $10.74 \%$ \\
\hline $\mathbf{5}$ & BIDV & $10.38 \%$ \\
\hline $\mathbf{6}$ & SHB & $9.66 \%$ \\
\hline $\mathbf{7}$ & VietinBank & $9.29 \%$ \\
\hline $\mathbf{8}$ & HDBank & $8.35 \%$ \\
\hline $\mathbf{9}$ & MBB & $7.52 \%$ \\
\hline $\mathbf{1 0}$ & SGB & $7.41 \%$ \\
\hline
\end{tabular}

Table 4.11 summarizes the final results in evaluating and rankings, which are previously detailed in table 4.10 after applying AHP method. We can see the changes of percentage of banks by criteria. $\mathrm{ACB}^{\prime}$ s percentages have change widely from each sub-criterion; finally it gets $12.98 \%$ at the top of the list. Coming very closely downwards are DAB, SeAbank etc., at the bottom of the table is SGB at $7.41 \%$.

This chapter discusses data analysis and the results of the current study. We first conduct setting to categorize the focused characteristics and steps towards this study will take place. Then, the selection analysis of each supplier is summarized in detail. 
The purpose is to find the final rankings of Vietnamese banking system according to the survey results from experts. From that, the final rankings were set up to get the results, which can be further discussed in the next chapter.

\section{CONCLUSIONS}

\subsection{Discussions and Managerial Implications}

This final chapter will comment on the results achieved, pointed out the conclusions and recommendations presented by the author, and the limitations encountered. On the other hand, the author gives a number of research directions for the development of the subject in the future and expands the application of AHP in practice.

In fact, many scholars and experts have already studied the related subjects of measurement performance, which includes the meaning of performance management, its elements and contents, and the measurement index ([21], [22],[23], [24]). On the contrary, the study of performance management is still not sufficient so far. In this study, the author conceder corporate intangible value and clearly understand performance management ability of each Vietnamese banking system by AHP. Besides, performance management is the key factor of high-tech companies' operation outcome, the author hopes those results can offer performance management as reference for the academia and professionals.

The results from the model are evaluated using the method of AHP quantification. AHP can compare the tiniest differences between providers through the numbers, charts and graphs. The results of detailed calculations to each level of the ladder system provide multi-faceted perspective. Strong ability to synthesize the components of the hierarchy and logic algorithms are not too complicated, but also help managers can examine each aspect and see the overview are all issues are considered.

In an organization that has always existed three important lines: The first line of communication throughout the system, the second is financial flows, also known simply as cash flow, and finally the material flow. Purchasing is one of the important tasks of the business because it is responsible for the physical input line of the organization. Increasing awareness of purchasing should be advanced position and its role in the enterprise is increasing. Most organizations now recognize closely related to purchasing strategy should the company access to parts purchasing increasingly more difficult. Information security requirements for these departments are increasingly stringent. 
The process of evaluation and selection of suppliers has long held bias in a qualitative sense, dependent on experience and emotions of those who have related responsibilities. Therefore, it is necessary to apply the typical methods such as quantitative analysis of this process - AHP presented in this study. With the aim of increasing the computational content of the evaluation process suppliers, especially the comparison of suppliers in the same industry as AHP has shown. This enables the analysis of all the providers and more scientific. Thus, this thesis would help the facility managers ensure objectivity to the reasonable decision.

Through the application of analytical methods to process steps or methods to compare providers evaluate other qualitative factors could improve and contribute to the financial organizations which then in the future they can apply and expand their business.

Moreover, the main evaluation criteria and sub-criteria have been quantified to ensure that most of the stages in the purchasing process. When evaluating partners is well supplied, all stages in the process of purchasing them achieve flawless collaboration.

\subsection{Limitations and Future Research}

This thesis utilizes the interview method access the expert groups and questionnaire surveys with data collected to be slightly biased and subjective experience.

The data primarily comes from the documents and reports out there, not yet homogeneous. Years missing data so that comparisons between providers and become limp.

The process measurement data collected are processed and applied scales also unsettled. The comparison between the criteria in suppliers has not yet met the stringent requirements of the equivalent. The transformation scales to scales AHP has many limitations.

It is possible to dig more theoretical model further evaluation. There are many criteria that can be used for model assessment. Every type of business and every business will have specific criteria in accordance with the individual's typical enterprise. It is important to note build an assessment model provider in accordance with industry characteristics and distinctions of the business. It should be tried to reach deep to the data source to the enterprise purchasing the thesis topic under direction of this form of anonymous real close to reality than now. 
Finally, the different measures provide distinct perspectives which help us have deeper conclusion about the association between working capital management and firm performance. Therefore, future researches should fill this research gap by generalizing findings using larger sample size in order to have more general, imperative vision as well as solutions for enterprises in many other fields. More measures of firm performance management as well as measurement performance components should be applied in future researches have better evaluation.

\subsection{Conclusions}

By this thesis, author would contribute to the banking system by providing the evaluating by the discussed criteria and sub-criteria. The research results suggest that performance management, which invest technology, improving quality, and structural management, is one of the main sources of competitive advantage for firms. This study argues that performance management is a necessary strategic tool for use against competitors. The emphasis on intellectual capital can help firms implement new initiatives for enhancing their performance. That means the technology on the security should be focused. Moreover, many experts and customers rate the INCOMES of a bank is really important, so that banks should build up the structural and marketing management to boost the IMCOMES. Other factors, including ATM and STAFF, are chosen at the certain level to evaluate a bank. 


\section{References}

[1] Yong-gang, C. U. I. (2004), A Method Based AHP: To Choose the Best Strategic Alliance Partner [J]. Journal of Tianjin University of Commerce, 1, 004.

[2] Korhonen, P., \&Voutilainen, R. (2006), Finding the most preferred alliance structure between banks and insurance companies. European Journal of Operational Research, 175(2), 1285-1299.

[3] Wang, T. C., \& Lin, Y. L. (2009), Applying the consistent fuzzy preference relations to select merger strategy for commercial banks in new financial environments. Expert Systems with Applications, 36(3), 7019-7026.

[4] N. T. Nguyen and T. T. Tran, Optimizing mathematical parameters of Grey system theory: An empirical forecasting case of Vietnamese tourism. Neural Comput.Appl., (2017), https://doi.org/10.1007/s00521-017-3058-9.

[5] T. T. Tran, Evaluating and forecasting performance using past data of an industry: An analysis of electronic manufacturing services industry. Int. J. Adv. Appl. Sci., 3(12) (2016a), 5-20.

[6] Seçme, N. Y., Bayrakdaroğlu, A., \&Kahraman, C. (2009), Fuzzy performance evaluation in Turkish banking sector using analytic hierarchy process and TOPSIS. Expert Systems with Applications, 36(9), 11699-11709.

[7] Ho, A., \& Baxter, R. A. (2011), Banking reform in Vietnam. Asia focus, (June).

[8] Min, D. M., Kim, J. R., Kim, W. C., Min, D., \& Ku, S. (1996), IBRS: Intelligent bank reengineering system. Decision Support Systems, 18(1), 97-105.

[9] N. T. Nguyen and T. T. Tran, Mathematical development and evaluation of forecasting models for accuracy of inflation in developing countries: A case of Vietnam. Discrete Dynamics in Nature and Society, 2015.

[10] N. T. Nguyen and T. T. Tran, Raising opportunities in strategic alliance by evaluating efficiency of logistics companies in Vietnam: A case of Cat Lai Port. Neural Comput. Appl., (2018b). https://doi.org/10.1007/s00521-018-3639-2.

[11] Kurttila, M., Pesonen, M., Kangas, J., \&Kajanus, M. (2000), Utilizing the analytic hierarchy process (AHP) in SWOT analysis - a hybrid method and its application to a forest-certification case. Forest Policy and Economics, 1(1), 41-52.

[12] Saaty, T. L. (2008), Decision making with the analytic hierarchy process.International journal of services sciences, 1(1), 83-98.

[13] Ngai, E. W. T. (2003), Selection of web sites for online advertising using the AHP. Information \& Management, 40(4), 233-242. 
[14] Salmeron, J. L., \&Herrero, I. (2005), An AHP-based methodology to rank critical success factors of executive information systems. Computer Standards \& Interfaces, 28(1), 1-12.

[15] Yu, H. C., Lee, Z. Y., \& Chang, S. C. (2005), Using a fuzzy multi-criteria decision making approach to evaluate alternative licensing mechanisms. Information\& management, 42(4), 517-531.

[16] Korhonen, P., \& Voutilainen, R. (2006), Finding the most preferred alliance structure between banks and insurance companies. European Journal of Operational Research, 175(2), 1285-1299.

[17] Seçme, N. Y., Bayrakdaroğlu, A., \&Kahraman, C. (2009), Fuzzy performance evaluation in Turkish banking sector using analytic hierarchy process and TOPSIS. Expert Systems with Applications, 36(9), 11699-11709.

[18] Arbel, A., \&Orgler, Y. E. (1990), An application of the AHP to bank strategic planning: The mergers and acquisitions process. European Journal of Operational Research, 48(1), 27-37.

[19] Chen, Z., \& Tan, J. (2011), Does bancassurance add value for banks? Evidence from mergers and acquisitions between European banks and insurance companies. Research in International Business and Finance, 25(1), 104-112.

[20] Sevkli, Mehmet.,Koh, S.C. Lenny., Zaim, Selim., Demirbag, Mehmet., Tatoglu, Ekrem. (2008), Hybrid analytical hierarchy process model for supplier selection. Industrial Management \& Data Systems, Vol. 108 No. 1. Pages 122-142.

[21] T. T. Tran, Forecasting strategies and analyzing the numbers of incoming students: Case in Taiwanese vocational schools. Int. J. Adv. Appl. Sci., 4(9) (2017), 8695.

[22] T. T. Tran, A strategic alliance study by performance evaluation and forecasting techniques: A case in the petroleum industry. Int. J. Adv. Appl. Sci., 5(2) (2018), 136147.

[23] N. T. Nguyen and T. T. Tran, A two-stage study of grey system theory and DEA in strategic alliance: An application in Vietnamese fertilizing industry. Int. J. Adv. Appl. Sci., 5(9) (2018a), 73-81.

[24] T. T. Tran, Evaluating and forecasting performance using past data of an industry: An analysis of electronic manufacturing services industry. Int. J. Adv. Appl. Sci., 3(12) (2016b), 5-20. 